\title{
MR. JUSTICE BRANDEIS, COMPETITION AND SMALLNESS: A DILEMMA RE-EXAMINED
}

The late Mr. Justice Louis D. Brandeis was born in Louisville, Kentucky on Nov. 13, 1856. The Yale Law Journal commemorates the hundredth anniversary of his birth with the following analysis of his economic thought.

THE attitude that government should take toward the large business firm was a question to which Louis Brandeis devoted a lifetime of thought. Distrustful of all concentration of power, he maintained that the giant corporation was a menace to the democratic process. ${ }^{1}$ Brandeis believed that the social development of the individual, neglected in a concentrated economy, would be fostered by an atmosphere of small business. He thus concluded society would profit if the government shattered the big enterprises which dominated industry.

The timeliness of the "bigness" problem which Brandeis strove to solve is shown by the complexities confronting antitrust policy today. The business unit which Brandeis condemned has become the nucleus of the modern American economy $;^{2}$ an era of industrial concentration has brought with it conflicting theories of business regulation. Many writers, impressed by the productive potential of contemporary big business, have urged that the economic performance of a firm or industry should determine the legality of a given market structure. ${ }^{3}$ Efficiency, progress and the profit pattern should thus be the controlling norms, rather than the degree of market power. ${ }^{4}$ Domination of an industry by a single giant firm or a handful of oligopolists ought not by itself be held violative of the antitrust laws; the government should be

1. United States Steel was, to Brandeis, an example of the dangers inherent in large corporations :

"[W] cannot maintain democratic conditions in America if we allow organizations to arise in our midst with the power of the [United States] Steel Corporation. Liberty of the American citizen cannot endure against such organizations." Statement of Brandeis, Hearings Before the Honse Committee on Investigation of United States Steel Corporation, 62d Cong., 2d Sess. 2862 (1912) (hereinafter cited as Steel Hearings); see also id. at 2835-72.

2. See Berle, The 20th Century Capitalist Revolution 25-27 (1954); Kaplan, Big Enterprise in a Competitive System cc. III, IV, VI (1954); Adelman, The Measurement of Industrial Concentration, 33 Rev. Econ. Stat. 269 (1951).

In 1947,139 of the country's 105,390 manufacturing corporations owned $45 \%$ of the assets of all manufacturing corporations. Adelman, supra at 277, 289.

3. See, e.g., Grifrin, An Economic Approach to Antrtrust Problears (1951); Lilienthal, Big Business: A New Era c. 21 (1952) ; United States Dep't of Conmerle, Effective Competition: A Report to the Secretary of Commerce by His Business Auvisory Counctl (1952).

4. See Grifrin, op. cit. supra note 3, at 63-85; E. S. Mason, The Current Status of the Monopoly Problem in the United States, 62 Harv. L. Rev. 1265, 1281-82 (1949). 
required to show that the monopoly power inherent in large market shares has been exercised to the detriment of the consumer. 5

Alternative standards for enforcement of the antitrust laws have been presented by the adherents of the "structural" approach. Wary of the possibility of abuse incident to monopoly power, ${ }^{6}$ they stress the number of independent sources of supply open to the consumer, as well as the relative market share held by each competitor. ${ }^{7}$ Diffusion of market power through a multiplicity of firms would, they claim, place automatic checks on the broad discretion enjoyed by business leaders in a concentrated economy. ${ }^{\mathrm{s}}$

Under the antitrust policy encompassed in the criteria of the "performance" school, a large business unit maintaining its present position of market dominance by superior efficiency and progressiveness would not be vulnerable to prosecution. Preservation of market power by economic performance alone would be considered a fair method of competition, in contrast to employment of coercive tactics to suppress potential competitors. ${ }^{2}$ Supporters of the structural approach to antitrust policy would generally favor dissolution of the industrial giant, regardless of the adequacy of its current performance. Some writers emphasize that the huge corporate enterprise can often be replaced by a limited number of smaller firms without sacrificing efficiency and progress. ${ }^{10}$ Other members of the structural school are less concerned with economic results than with the social advantages of decentralized industrial power;

5. "The law ... does not make the mere size of a corporation, however impressive, or the existence of unexerted power on its part, an offense, when unaccompanied by unlawful conduct in the exercise of its power." United States v. International Harvester Co., 274 U.S. 693, 708 (1927) (opinion by Sanford, J.); see also United States v. United States Steel Corp., 251 U.S. 417, 451 (1920).

Although Mr. Justice Brandeis was a member of the Supreme Court when United States Steel was decided, he disqualified himself from consideration of the case on the basis of his testimony before the congressional committee investigating that corporation. He subsequently disqualified himself from consideration of International Harvester. Thus, without the opportunity to express his views in dissent, he listened in silence as the Court issued decisions directly contradictory of his economic philosophy. See Hamilton, The Jurist's Art, 31 Colum. L. Rev. 1073, 1086 n.66 (1931).

6. "[T] he material consideration in determining whether a monopoly exists is not that prices are raised and that competition actually is excluded but that power exists to raise prices or to exclude competition when it is desired to do so." American Tobacco Co. v. United States, 328 U.S. 781, 811 (1946) (opinion by Burton, J.).

7. See, e.g., Edwards, Maintaining Competition 9-10 (1949); Bowman, Tozvard Less Monopoly, 101 U. PA. L. Rev. 577, 631-41 (1953); Stigler, The Extent and Bases of Monopoly, 32 Am. Econ. Rev. 1, 2-3 (Supp., June 1942).

8. For a comparison of the market performance and market structure tests of monopoly, see Dirlam \& Kahn, FaIr Competition: The Law and Econonics of Antitrust Policy $29-42$ (1954); E. S. Mason, supra note 4.

9. Even the foremost defenders of big business concede that certain unfair business practices should be "per se" violations of the antitrust laws, regardless of the end results. See GRIFFIN, op. cit. supra note 3, at 52 .

10. See, e.g., Adams \& Gray, Monopoly in America $10-17$ (1955) ; Edwards, Maintaining Competition 113-20 (1949); Rostow, The New Sherman Act: A Positive Instrument of Progress, 14 U. CHI. L. REv. 567, 568 (1947). Many writers stress the 
they would recommend extensive fragmentation of the large unit, even at the cost of some impairment of performance. ${ }^{11}$

However, the preservation of a relatively atomistic market structure may well conflict with the economies of large-scale firms or be otherwise unsuited to the economic realities of an industry. If so, a dilemma will present itself: in order to perpetuate diffusion of industrial power, the government itself will have to sanction and effectuate limitations on competitive behavior. For example, expansion by a handful of efficient small firms to the optimum economic size may eventually bring about the industrial concentration responsible for the original fragmentation. ${ }^{12}$ Also, unless small independent producers are permitted to enter into agreements regulating their marketing practices, they may destroy one another through excesses of competition. ${ }^{13}$ Accordingly, to preserve that market structure considered most socially desirable, government regulation of the economy must paradoxically take the form of restricting, rather than increasing, the economic competition generally deemed the crux of a free enterprise system. ${ }^{14}$

feasibility of breaking up multi-plant enterprises. See FTC, REPORT on the Divergence Between Plant and Conpant Concentration, 1947 (1950).

11. Douglas, Democracy and Finance 14-16, $290-91$ (1940); Simons, Economic Policy for a Free Society 57-60 (1948); cf. Edwards, Big Business and the Policy of Codipetition 1-10 (1956) ; Stocking \& Watkins, Monopoly and Free Enterprise 554 (1951); E. S. Mason, The New Competition, 43 Y ALE REv. 37, 41-42, 48 (1953).

"Congress ... did not condone 'good trusts' and condemn 'bad' ones; it forbad all. Moreover, in so doing it was not necessarily actuated by economic motives alone. It is possible, because of its indirect social or moral effect, to prefer a system of small producers, each dependent for his success upon his own skill and character, to one in which the great mass of those engaged must accept the direction of a few."

United States v. Aluminum Co. of America, 148 F.2d 416, 427 (2d Cir. 1945) (opinion by L. Hand, J.); see also id. at $428-29$.

12. For a discussion of the conflict between economies of scale and the maintenance of multi-firm industries, see Bain, Price Theory 153-54, 183-84 (1952); Burns, The Decline of Coarpetition 8-9 (1936); Galbraith, American Capitalism c. IV (1952); E. S. Mason, The Current Status of the Monopoly Problem in the United States, 62 HARv. L. Rev. 1265, 1269 (1949).

13. Cf. Appalachian Coals, Inc. v. United States, 288 U.S. 344 (1933).

14. "[T]he fatal objection to this policy [a reduction in the size and an increase in the number of firms to resurrect competition] is that it is self-defeating; it is fundamentally inconsistent with the maintenance of competition. Wherever a business attained the maximum size permitted under the law, the stimuli present under free competition would operate only in a very modified form. The inducement to improve methods of production in order to reduce prices and thereby capture an increasing share of the total business in the industry is eliminated. There is no further inducement to price competition by such a frm."

Burns, The Decline of Competition 526 (1936).

Many commentators have lamented the anti-competitive consequences of an antitrust policy directed against market share as such. See United States Dep't of Comanerce, EFfective Cosipetition 16 (1952); Griffin, op. cit. supra note 3, at 31-32; cf. United States y. Aluminum Co. of America, 91 F. Supp. 333, 415 (S.D.N.Y. 1950). In this 
This dilemma is clearly reflected in the writings of Brandeis. Phrasing the question of big business in social and political as well as in economic terms. Brandeis foreshadowed both the conclusions and the problems of the structural school. Before his appointment to the Supreme Court in 1916. Brandeis had asserted that the small firm was economically more efficient than its giant counterpart. He thus did not immediately encounter the dilemma confronting the structural school, since he believed that an economy of small units was consistent with economic realities and did not have to be fostered by competitive restrictions. Yet the dilemma becomes apparent in several of Brandeis' opinions as a member of the Supreme Court; his concern for small business led him to resolve it by sacrificing competitive principles.

\section{The Curse of Bigness: Ideas Before 1916}

Brandeis condemned the growing concentration of industrial power in the United States in the late nineteenth and early twentieth centuries as both socially unhealthy and economically wasteful. ${ }^{15}$ In contrast to the prevailing opinion of his day toward the trust movement that was transforming the economy, ${ }^{16}$ Brandeis labeled the trusts pathologies, regrettable deviations from the normal development of capitalism. ${ }^{17}$ The corporate mechanism, he asserted, was the device through which a handful of individuals gained unlimited control over "other people's money," and dominated the interests of employees and consumers. ${ }^{18}$

context, compare the interpretation of United States v. Aluminum Co. of America, 148 F.2d 416 (2d Cir. 1945) in Report of the Attonney General's National Committee to Study the Antitrust Laws 60 (1955) (hereinafter cited as ATr'y GEN. Rep.) awth that in GrIfFin, op. cit. supra note 3, at 29-31. See also E. S. Mason, The Current Status of the Monopoly Problem in the United States, 62 HARv. L. Rev. 1265, 1273-75 (1949) ; Adelman, Effective Competition and the Antitrust Laws, 61 Harv. L. Rev. 12s9, 1310-11 (1948).

15. "I think we are in a position, after the experience of the last 20 years, to state two things: In the first place, that a corporation may well be too large to be the most efficient instrument of production and of distribution, and, in the second place, whether it has exceeded the point of greatest economic efficiency or not, it may be too large to be tolerated among the people who desire to be free."

Statement of Brandeis, Hearings Before the Senate Committee on Interstate Commerce Pursuant to S. Res. 98, 62d Cong., 2d Sess., vol. I, at 1174 (1911) (hereinafter cited as Interstate Commerce Hearings).

16. Cf. Wallace, Industrial Markets and Public Policy: Some Major Problcms, 1 PuB. Policy 59, 60-61 (1940). Though the trusts were sometimes criticized for utilizing unfair competitive methods or charging unreasonable prices, most commentators believed that the trusts were justified by superior efficiency and should not be broken up. See, e.g., Bogart, The Economic History of the United States 424-71 (2d ed. 1914); Moody, The Truth About the Trusts 494-96, 500-02 (1904) ; Seager \& Gulick, Trust and Corporation Problems 72-85, 654-71 (1929). But of. Bullock, Trust Literature: $A$ Survey and Criticism, in Trusts, Pools and CoRporations 428 (Ripley ed. 1905).

17. See Brandeis, Shall We Abandon the Policy of Competition? 18 Case \& CoM. 494, 495 (1912) ("There are no natural monopolies to-day in the industrial world."); Lerner, The Social Thought of Mr. Justice Brandeis, 41 Yale L.J. 1, 18 (1931).

18. "Large dividends are the bribes which the managers tender the small investor 
Such an unequal distribution of economic power had dire repercussions in a democracy, according to Brandeis. ${ }^{19}$ He saw the rise of bigness as causing the extinction of the independent businessman, that entrepreneur whom economic theory had glorified and held responsible for the successful functioning of capitalism. ${ }^{20}$ Because he believed that "absolute power inevitably leads to abuse,"21 Brandeis thought that the tendency of the trust leaders to exploit labor and suppress unionism was a natural consequence of inequality of bargaining position. ${ }^{22}$

The business unit to Brandeis was more than an economic organization; it was also an instrument of social growth. ${ }^{23}$ As the owners of individual enterprises and their helpers became the dependent servants of big business, Brandeis warned that society was being transformed into a nation of robots, unfit to perform the duties which a democratic government demanded of its citizens. ${ }^{24}$ In the large companies, labor was inevitably barred from participation in managerial functions; consequently the creative potential of the average

for the power conferred to use other people's money." Interstate Commerce Hearings 1157 .

Brandeis believed that the irresponsibility of the trusts was largely attributable to the separation of ownership and control which characterized the publicly held corporation. See id. at 1156-57; Steel Hearings 2843; address by Brandeis, The Regulation of Competition Against the Regulation of Monopoly, Nov. 1, 1912, printed in The Curse of Brgness 109, 110-11 (Fraenkel ed. 1934); Louis K. Liggett Co. v. Lee, 288 U.S. 517, 565 (1933) (dissenting opinion of Brandeis, J.).

19. "Concentration of power has been shown to be dangerous in a democracy, even though that power may be used beneficently." Statement of Brandeis, Final Report and Testimony of the Commission on Industrial Relations, S. Doc. No. 415, 64th Cong., 1st Sess., vol. VIII, at 7663 (1915) (hereinafter cited as Industrial Relations Testimony); see also Interstate Commerce Hearings 1166, 1167.

20. "[T]he displacement of the small independent business man by the huge corporation with its myriad of employees, its absentee ownership, and its financier control, presents a grave danger to our democracy. The social loss is great; and there is no economic gain."

Brandeis, Cutthroat Prices-The Competition That Kills, Harper's Weekly, Nov. 15, 1913, p. 12, reprinted in Brandeis, Business-A Profession 242, 260 (1933 ed.); see also Brandeis, How the Combiners Combine, Harper's Weekly, Nov. 29, 1913, pp. 11-12, reprinted in Brandeis, Other People's Money 28, $48-49$ (1932 ed.); A. T. Mason, The BruNDEIS WAY 46 (1938) ; Richberg, The Industrial Liberalism of Justice Brandeis, 31 Colum. L. Rev. 1094, 1096 (1931) ; Louis K. Liggett Co. v. Lee, 288 U.S. 517, 56S-69, 580 (1933) (dissenting opinion of Brandeis, J.).

21. Address by Brandeis, The New England Transportation Monopoly, Feb. 11, 1908, printed in Brandeis, Business-A Profession 262, 278 (1933 ed.).

22. Industrial Relations Testimony 7658-63; Steel Hearings 2855-57, 2870; address by Brandeis, Big Business and Industrial Liberty, Feb. 10, 1912, printed in THE CuRse of Bigness 38 (Fraenkel ed. 1934).

23. "It is the development of manhood to which any industrial and social system should be directed." Industrial Relations Testimony 7659.

24. See Steel Hearings 2841-43; Interstate Commerce Hearings 1166; miscellaneous addresses by Brandeis from 1904 to 1915, printed in Brandeis, Business-A Profession 16-17, 29-32, 58-59, 342, 366-67 (1933 ed.); address by Brandeis, Industrial Co-operation, May, 1905, printed in The Curse of Bigness 35 (Fraenkel ed. 1934); see also letter from 
citizen was not developed within the work setting. ${ }^{25}$ In Brandeis' opinion, an important advantage of the small concern was the sharing by labor of responsibility for the business's success. As a member of a cooperative enterprise, the individual worker contributed more to the job and got more out of it. $^{26}$

For Brandeis big business was more than a social and political menace. He further insisted that the trusts could not be justified in terms of the dual economic standards of efficiency and progress. He took issue with that school of thought which considered the giant corporation the inevitable product of technological trends. ${ }^{27}$ Brandeis attributed the financial success of the early twentieth century trusts primarily to their monopolistic control over prices, and not to inherent cost-saving advantages. ${ }^{28}$

Brandeis felt that an increase in size of a business unit after a discernible point caused a sharp decrease in economic performance-a result of his strong belief in the inefficiencies of management in a large firm. It was his opinion that the "success or failure of an enterprise depends usually upon one man; upon the quality of one man's judgment, and, above all things, his capacity to see what is needed and . . . to direct others."29 $\mathrm{He}$ did not think a firm could be efficiently managed unless it was small enough for the business leader to participate actively in all operating decisions. ${ }^{30}$ And since there were

Brandeis to Norman Hapgood, Nov. 23, 1932, printed in A. T. MAson, Branders : A Free MAN's LIFE 602 (1946) ; letter from Brandeis to Robert Bruère, Feb. 25, 1922, printed in id. at 585 .

25. "The grave objection to the large business is that, almost inevitably, the form of organization, the absentee stockholdings, and its remote directorship prevent participation ... of the employees in such management. .. Thus we lose that necessary cooperation which naturally flows from contact between employers and employeesand which the American aspirations for democracy demand."

Industrial Relations Testimony 7660. See also Brandeis, The Living Law, 10 ILx. L. Rev. 461, 463 (1916).

26. Industrial Relations Testimony 7659-60, 7663-64. See also A. T. MAson, BranDeIs: A Free Man's LIFE 642 (1946).

27. See notes 16,17 supra.

Brandeis believed that both lax enforcement and inadequacies of federal antitrust law prior to 1914 were major factors in the success of the trust movement. See statement of Brandeis, Hearings Before the Hosse Committee on the Judiciary on Trust Legislation (Clayton Committee), 63d Cong., 2d Sess., ser. 7, pt. 16, at 665 (1914).

28. Brandeis, Competition (1913), in The Curse of BIGNess 112 (Fraenkel ed. 1934) ; Brandeis, Trusts, the Export Trade and the New Party, Collier's Weekly, Sept. 21, 1912, p. 10, reprinted in Brandeis, Business-A Profession 225 (1933 ed.); Brandeis, Trusts, Efficiency and the New Party, Collier's Weekly, Sept. 14, 1912, p. 14, reprinted in id. at 205; Brandeis, Shall We Abandon the Policy of Competition?, 18 CASE \& CoM. 494 (1912); Interstate Commerce Hearings 1148, 1157, 1245.

29. Id. at 1147 .

30. Id. at 1147-48; Brandeis, Competition (1913), in The Curse of Bigness 112, 116-17 (Fraenkel ed. 1934); argument of Brandeis, Evidence Taken by the Interstate Commerce Commission in the Matter of Proposed Advances in Freight Rates by Carricrs, S. Doc. No. 725, 61st Cong., 3d Sess., vol. VIII, at 5255-56 (1911). 
discernible limits on human capacity, there were corresponding limits on the maximum size of a manageable unit. ${ }^{31}$

Brandeis also considered the large corporation, which necessarily possessed substantial elements of monopoly power, an ineffective instrument of industrial progress. He thought the trusts of his day had shown extreme sluggishness in improving manufacturing techniques. Secure in their position and guaranteed the current level of profits by following standard methods, they had been content to adopt an attitude of complacency, with the consequent deceleration of technological advancement. ${ }^{32}$

Brandeis' belief in the superior economic performance of the small business enterprise, combined with his distrust of private concentration of power, naturally led him to advocate government dissolution of the giant corporations of his day. Replacement of the trust by a multiplicity of small units was for Brandeis merely restoration of a normally functioning brand of capitalism; it was not an attempt to create competition artificially. Moreover, he insisted it was not necessary for the state to limit the natural growth of competitors in order to preserve competition among large numbers. He saw nothing in our industrial history which indicated that an enterprise could gain control of a market solely by reason of superior efficiency and progressiveness. ${ }^{33}$ Rather, the role of the government in Brandeis' ideal economic world was to prevent those unfair practices which the trusts had originally used to usurp market control. Merger of independents to obtain monopoly power over prices, or annihilation of competitors by price discrimination, were not the legitimate economic weapons of a capitalist. $^{34}$ While the state acted to police such tactics, the incentives inherent in a

31. Address by Brandeis, The New England Transportation Monopoly, Feb. 11, 1908, printed in Brandeis, Business-A Profession 262, 275-76 (1933 ed.).

32. Brandeis, Big Men and Little Business, Harper's Weekly, Jan. 3, 1914, p. 11, reprinted in Brandeis, Other People's Money 135, 149-52 (1932 ed.) ; Brandeis, Compctition (1913), in The CuRse of Bigness 112, 118-21 (Fraenkel ed. 1934); Interstate Commerce Hearings 1149-50, 1208.

33. See Brandeis, Competition (1913), in The Curse of Bigness 112, 114-16, 124 (Fraenkel ed. 1934); address by Brandeis, Social Justice and the Trusts, Dec. 18, 1912, quoted in A. T. MAson, Branders: A Free Man's LrFe 352 (1946); Interstate Commerce Hearings 1234, 1245.

34. For discussion by Brandeis of unfair competitive methods, see statement by Brandeis, Hcarings Before the House Conmittee on Interstate and Foreign Commerce on Regulation of Prices, 64th Cong., 1st Sess. 198 (1915) ; Brandeis, Cutthroat PricesThe Compctition That Kills, Harper's Weekly, Nov. 15, 1913, p. 12; Brandeis, The Solution of the Trust Problem, Harper's Weekly, Nov. 8, 1913, p. 18; Brandeis, Shall We Abandon the Policy of Competition?, 18 CASE \& Cosr. 494 (1912); Interstate Commerce Hearings 1162, 1170, 1173; cf. Mason, The BrandeIs WaY 68, 72 (1938). See also FTC v. Gratz, 253 U.S. 421, 429 (1920) (dissenting opinion, of Brandeis, J.); Leitch Mfg. Co. v. Barber Co., 302 U.S. 458 (1938) (opinion by Brandeis, J.) ; Carbice Corp. v. American Patents Development Corp., 283 U.S. 27 (1931) (opinion by Brandeis, J.).

The unfair practices stressed by Brandeis were discriminatory sharpshooting, spying on competitors, espionage, bribery of competitors' employees and government officials, establishing bogus competition and "fake independents," discrimination against producers or customers who would not deal exclusively with the combination, railroad rebates, exclusion of competitors from access to raw material, and tying contracts. 
system of fair competition of many producers would guarantee optimum performance. ${ }^{35}$

Thus, the economic ideal expounded by Louis Brandeis prior to his appointment to the Supreme Court in 1916 resembled the competitive model developed by classical economic thought. ${ }^{36}$ For Brandeis as for classical economics, an economy dominated by a multitude of small units was a political and economic blessing. Diffusion of private power meant that no producer would have any power to misuse. ${ }^{37}$ The effort of the individual competitor to increase his market share by improving product quality or reducing production cost meant that consumers would enjoy the fruits of efficiency and progress.

In one respect, however, the classical system and the pre-1916 Brandeis system diverged sharply. For the classical economist, trade unions not only were a monopolistic interference with the free functioning of the factor market but also impeded the mobility of labor by restrictive provisions. ${ }^{38}$ In contrast, Brandeis believed that "constructive" unionism had a real place in the American economy. Labor organizations would act as a bulwark against the tendency of the individual competitor to maximize his profit by lowering the wages or lengthening the hours of his employees. ${ }^{39}$ Unlike the trusts, which possessed the financial resources to withstand long strikes and other self-help activities of labor, the small producer of the Brandeis ideal would have to meet his combined employees on equal terms. ${ }^{40}$ To guard against the possibility of a union's dominating the individual employer, just as he believed

35. Brandeis, Competition (1913), in The Curse of Brgness 112 (Fraenkel ed. 1934); address by Brandeis, The Regulation of Competition Against the Regulation of Monopoly, Nov. 1, 1912, printed in id. at 109; Brandeis, The New Haven-An Unregulatcd Monopoly (1912), in Besiness-A Profession 286, 295-99 (1933 ed.); Interstate Commerce Hearings 1157-58, 1235-36; see also Lief, Brandeis: The Personal History of an Aarerican Ideal 123 (1936).

36. See Bain, Price Theory c. 4 (1952); Galbraith, American Capitalism cc. II-IV (1952).

37. Brandeis' distrust of unchecked power in private hands had a conceptual influence on his political as well as his economic thinking. E.g., in Myers v. United States, 272 U.S. 52 (1926), Brandeis dissented from the Court's holding that the President, without Senatorial approval, could remove from office a postmaster appointed with the advice and consent of the Senate:

"The doctrine of the separation of powers was adopted ... not to promote efficiency but to preclude the exercise of arbitrary power. The purpose was, not to avoid friction, but, by means of the inevitable friction incident to the distribution of the governmental powers among three departments, to save the people from autocracy."

Id. at 293 (dissenting opinion of Brandeis, J.).

38. Cf. Simons, Some Reflections on Syndicalism, 52 J. PoL. EcoN. 1, 7-8, 12 (1944).

39. Industrial Relations Testintony 7657-81; Steel Hearings 2855-58, 2862, 2870; Interstate Commerce Hearings 1155-56, 1180-83; address by Brandeis, The Employcr and Trades Unions, April 21, 1904, printed in Brandeis, Business-A Profession 13 (1933 ed.). See also The Curse of Bigness $43-47$ (Fraenkel ed. 1934).

40. Industrial Relations Testimony 7658-63. 
the giant corporation dominated labor, Brandeis advised the independent competitors of each industry to form an employer's organization for collective bargaining purposes. ${ }^{41}$ Moreover he insisted that an irresponsible union was as much of a social menace as an omnipotent corporation. ${ }^{42}$

\section{The Dilemima: Its Background}

Brandeis' analysis of the economic potential of the large enterprise has been severely questioned. Commentators have called attention to the economies of large-scale production and distribution, ${ }^{43}$ the contribution of modern managerial techniques to efficient corporate leadership, ${ }^{44}$ the technological advancement springing from the research laboratories of the large companies. ${ }^{45}$ Such arguments failed to deter Brandeis' crusade against bigness; as a member of the Supreme Court, he continued to warn of the social and political disadvantages of a concentrated economy. ${ }^{40}$ However the economic wastes of the large enterprise- a theme of his earlier pronouncements-are not stressed in his opinions.

41. Brandeis, Shall We Abandon the Policy of Competition?, 18 CASE \& CoMr. 494, 496 (1912); Intcrstate Comnterce Hearings 1183, 1250.

42. See note 39 supra.

Brandeis opposed the closed shop, because he believed union leaders were thereby accorded too great a control over the labor market. "I should no more think of giving absolute power to unions than I should of giving to capital monopoly power." Interstate Commerce Hearings 1180 . He favored instead a preferential union shop, whereby preference in employment was given a "qualified" union member. Industrial Relations Testimony 7680-81; see also A. T. Mlason, BRANdeIS-A Free MAN's Life 294-315 (1946).

For a complete picture of Brandeis' views on the benefits and responsibilities of unionism, see his opinions in Senn v. Tile Layers' Protective Union, 301 U.S. 468 (1937) ; Bedford Cut Stone Co. v. Journeymen Stone Cutters' Ass'n, 274 U.S. 37, 56 (1927) (dissenting opinion); Dorchy v. Kansas, 272 U.S. 306 (1926); Truax v. Corrigan, 257 U.S. 312, 354 (1921) (dissenting opinion); Duplex Printing Press Co. v. Deering, 254 U.S. 443, 479 (1921) (dissenting opinion); Hitchman Coal \& Coke Co. v. Mitchell, 245 U.S. 229, 263 (1917) (dissenting opinion).

43. See, e.g., Lilienthal, Big Business: A New Era (1952); Drucker, The Concept of the CoRporation (1946).

A few modern writers have evaluated Brandeis' views on the efficiency of big business. Compare Drucker, op. cit. supra at 224 ("Mr. Brandeis maintained that bigness was economically inefficient. We know today that in modern industrial production ... the small unit is not only inefficient, it cannot produce at all.") with QuIN, I QUIT Monster Business 21 (1948) ("The late Justice Brandeis saw with prophetic vision the decreasing efficiency of monster companies as they were to reach out for more and mare subsidiaries.").

44. See, e.g., Schumpeter, Capitalisa, Socialism, and Democracy cc. VII, VIII (2d ed. 1942); Maclaurin, Inventton and InNovation in the Radio Industry cc. VIII, IX (1949).

45. Sec, c.g., Gordon, Business Leadership in the Large Corporation (1945).

46. See, e.g., Louis K. Liggett Co. v. Lee, 288 U.S. 517, 565 (1933) (dissenting opinion):

"The typical business corporation of the last century, owned by a small group of individuals, managed by their owners, and limited in size by their personal wealth, 
Since Brandeis, at least prior to 1916 , believed that the small unit was capable of a level of economic performance superior to that of the large firm, he had logically concluded that the former would do better than hold its own if given merely the chance to compete with the latter on equal terms. ${ }^{47}$ Thus, the government need only "make competition possible" to destroy bigness; it did not have to subsidize the small firm in the competitive struggle or give it advantages that were denied the large enterprise. Confident of the economic potential of the small firm, Brandeis had not fully considered the need to protect small business by obstructing the natural operation of competitive forces.

As a member of the Supreme Court, Brandeis was squarely faced with this problem in a series of cases. And in his opinions Brandeis sanctioned noncompetitive concerted action by individual producers, as well as affirmative government aid for selected competitors, if the result of such conduct was to perpetuate smallness. His willingness to approve sharp deviations from competitive principles in order to avoid a concentrated economy indicates the dilemma of the apostles of small business.

\section{Competition and the Fourteenth Amendment .}

\section{Discriminatory State Taxation}

In Quaker City Cab Co. v. Pennsylwania, ${ }^{48}$ the Supreme Court held unconstitutional a state tax on the gross receipts earned by corporations from the intrastate transportation of freight or passengers. Observing that plaintiff corporation was competing with individuals and partnerships that escaped taxation under the statute, the majority asserted that the corporate tax would violate the equal protection clause of the Fourteenth Amendment if the classification made by the statute was found to be arbitrary. ${ }^{49}$ The Court held a discrimination based solely on the character of the business's owner an illogical ground of distinction. ${ }^{50}$

Dissenting, Mr. Justice Brandeis maintained that a state was not constitutionally prohibited from subjecting a corporation to heavier taxation than

is being supplanted by huge concerns in which the lives of tens or hundreds of thousands of employees and the property of tens or hundreds of thousands of investors are subjected, through the corporate mechanism, to the control of a few men."

47. "I believe if it were possible today to make the corporations act in accordance with what doubtless all of us would agree should be the rules of trade no huge corporation would be created, or, if created, would be successful. . . . I am so convinced of the economic fallacy in a huge unit that if we make competition possible, if we create conditions where there could be reasonable competition ... these monsters would fall to the ground. . .."

Interstate Commerce Hearings 1170.

48. 277 U.S. 389 (1928).

49. The Court held that the equal protection clause applied to corporations as well as natural persons. Id. at 400 .

50. Id. at 399-402. 
its unincorporated competitors. He thought that the classification made by the statute was not arbitrary, but a reflection of inherent dissimilarities in forms of business organization. In supporting the distinction as rational, Brandeis reiterated the harmful social consequences which he felt accompanied the aggregation of capital through corporations: the "insidious menace to the liberty of the citizen," the "subjection of labor to capital," the impairment of individual initiative and lessening of creative power. ${ }^{51}$

Brandeis elaborated these ideas in his dissenting opinion in Louis K. Liggett Co. v. Lce. ${ }^{52}$ In this case the Court held constitutional that part of a Florida law which provided that the license fee for the operation of a single retail store should increase progressively with the total number of stores owned and operated by the licensee. The Court felt that differences in the methods of merchandising employed by a chain of stores and the individually operated single store justified the state's imposition of a heavier tax per unit on the multi-unit enterprise. ${ }^{53}$ But a majority of the Court voided as arbitrary that provision of the statute which further increased the fee per store if the licensee operated stores in more than one county. 54

Disagreeing with the latter holding, Brandeis observed that the legislation was not designed primarily to raise revenue but "to protect the individual, independently-owned, retail stores from the competition of chain stores." The plaintiffs in this case were thirteen corporations, each of which operated an intrastate chain of retail stores. Since the opportunity of doing business in corporate form was a state-granted privilege, the sovereign could attach any conditions to its exercise which it desired. Accordingly, since the corporation was free to reject the offer, the state was within its rights if it charged a higher price for the privilege of locating stores in more than one county. ${ }^{56}$

Underlying the anti-chain store legislation, Brandeis saw a public fear of the domination of retail distribution by the large corporation:

"[T] he chief aim of the Florida statute is apparently to handicap corporate chain stores-that is, to place them at a disadvantage, to make their success less probable. No other justification of the discrimination in license fees need be shown; since the very purpose of the legislation is to create inequality and thereby to discourage the establishment, or the maintenance, of corporate chain stores. ..." "57

51. Id. at 410 .

52. 288 U.S. 517 (1933).

53. Id. at 532-33.

54. Id. at 533-34. The majority opinion stressed that the establishment of a new store in a different county did not by itself justify imposition of a higher tax on those stores which had previously been established within a single county.

55. Id. at 541 .

56. Id. at 545 .

57. Id. at 575 .

Emphasizing that the individual retailers of Florida were engaged in "a struggle for existence," $i d$. at 568 , Brandeis pointed out that a goal of the statute was "to preserve the competition of the independent stores with the chain stores," $i d$. at 569-70. "[I]nstead of absolutely prohibiting the corporate chain store, the State might conclude that it should 
Brandeis' support of discriminatory taxation, designed solely to place one group of market participants at a competitive disadvantage, is in direct conflict with the economic philosophy of the classical system of free enterprise. ${ }^{58}$ In classical economic terms, such government subsidization of favored competitors to improve their chances of commercial success would impede the operation of the natural laws of competition, whereby the marginal producer was driven from the market by his more efficient rivals. By subjecting the chain store to a heavier burden of taxation than the owner of a single store, the state would also be discouraging the establishment of optimum scale enterprises within the industry, to the consumer's detriment. ${ }^{59}$

Although Brandeis had, prior to his Court appointment, advocated state action to eliminate unfair competitive methods, he significantly did not justify Florida's discriminatory taxation of chain store operators in terms of this objective. Nowhere in the course of his long Liggett dissent does Brandeis suggest that the chains have resorted to unfair practices to slaughter the independent proprietor. True, some observers have felt that, prior to the passage of the Robinson-Patman Act, ${ }^{60}$ a major factor in the success of the chain store was not superior efficiency but rather the bargaining advantages conferred by size. ${ }^{61}$ Although use of buying power to obtain price concessions

first try the more temperate remedy of curbing the chain by imposing the handicap of discriminatory license fees." Id. at 574.

Brandeis observed that the Florida statute by its terms did not apply only to large corporate chains, but also to a small number of stores commonly owned by either a corporation or an individual. But he added that the chain tax law was clearly directed against the large corporations and was framed in broader terms to avoid constitutional difficulties. Id. at 576.

58. Although the Court's sole function in the Liggett case was to decide the constitutionality of the challenged statute, Brandeis' defense of anti-chain store taxes in his dissent clearly reflects his personal belief in the wisdom of this form of legislation. Such a conclusion is bolstered by Brandeis' letter to Fred Howe, March 22, 1936, contained in the Brandeis papers in the Library of the University of Louisville Law School. Asked to suggest devices to limit corporation size in order to encourage small enterprise, Brandeis replied:

"To limit corporation size, I suggest an annual excise tax, rapidly progressing in the rate as the total capitalization of the corporation rises-the amount of the capitalization to be measured by the aggregate face value of (a) its stock, bonds and similar securities (all stocks to have a stated par value) plus (b) the aggregate value of the stocks, bonds and other securities of all subsidiary or other corporations of which it holds as much as twenty per cent of the outstanding stock and/or bonds or other securities."

59. For an economic criticism of anti-chain store taxation, see, e.g., MoRrIs, THE Economics of the Spectal Taxation of Charn Stores 4-5 (1937); Burns, The Antitrust Laws and the Regulation of Price Competition, 4 LAw \& Contearr. ProB. 301, 320 (1937) ; FTC, Final Report on the Chain-Store Investigation, S. Doc. No. 4, 74th Cong., 1st Sess. 91-92 (1934); $c f$. Hoffman, Large-Scale Organization in the Food IndusTRIES 154-56 (TNEC Monograph 35, 1940).

60. 49 Stat. 1526 (1936), 15 U.S.C. $\$ 13$ (1952), amending 38 Stat. 730 (1914).

61. See Austin, Price Discrinination and Related Problemis Under tae Robinson-Patman Act 8-11 (1953 ed.); H.R. Rep. No. 2287, 74th Cong., 2d Sess. 3-6, 17 
may be classified an "unfair method of competition,"62 Brandeis' support of discriminatory taxation in the Quaker City and Liggett cases is not predicated on this ground. Moreover, discriminatory taxation would appear to be an inappropriate regulatory device to annul the bargaining advantages enjoyed by the larger firms. Such a tax is attomatically imposed on a designated class of business enterprises, without a demonstration that a specific competitor is profitably employing "unfair" bargaining pressures. ${ }^{63}$

Brandeis' defense of discriminatory taxation in the Quaker City and Liggett cases is basically in social terms. ${ }^{64}$ Although the large corporate unit is legiti-

(1936) ; S. Rep. No. 1502, 74th Cong., 2d Sess. 3 (1936); FTC, Final Report on the Chain-Store Investigation, S. Doc. No. 4, 74th Cong., 1st Sess. 24-28, 53-63 (1934).

The cost-saving advantages which chain stores enjoy over independents are generally attributed both to the bargaining advantages of size and to the economies of large-scale operation. See Beckiman \& Nolen, The Chain Store Problem c. IV (1937) ; Fulda, Fand Distribution in the United States, The Struggle Between Independents and, Chains c. II (1951); Hofman, op. cit. stipra note 59, c. VII; ZoRn \& Feldaran, BusINess Under the New Price Laws c. I (1937); McNair, Marketing Functions and Costs and the Robinson-Patman Act, 4 LAw \& Contems. ProB. 334 (1937). In State Board of Tax Commissioners v. Jackson, 283 U.S. 527 (1931), the Supreme Court sustained the constitutionality of an annual license tax on stores increasing progressively with the total number of stores under common ownership. Concluding that a distinction between chain stores and independently owned units was a reasonable basis of classification for tax purposes, the Court, per Roberts, J. (Brandeis concurring), identified differences in merchandising employed by the two types of distributive organizations. Most of these differences relate to the efficiencies and economies effected through mass distribution; see id. at 534-35. See also the opinion of the Florida Supreme Court in the Liggett case, Louis K. Liggett Co. v. Amos, 104 Fla. 609, 622-23, 627-28, 141 So. 153, 158, 160 (1932) ("We know of no reason ... for relieving superior skill, initiative, and industry from the payment of a tax.").

62. But, for the position that the exercise of bargaining power by large retail organizations is a legitimate and beneficial feature of the modern American economy, see GaLbraith, American Capitalism 147-50 (1952); Council of Economic Advisors, Third Annual Report to the President 15 (1948); Rowe, Price Discrimination, Competition, and Confusion: Another Look at Robinson-Patman, 60 YALE L.J. 929, 950-51 (1951). See also authorities cited note 122 infra.

63. For example, a retail unit may be vertically integrated with its suppliers, or may purchase the entire output of a manufacturing unit. In such a case, price discrimination, the major evil associated with exertion of bargaining pressures by large purchasers, would not be responsible for cost savings. See FULDA, op. cit. supra note 61, at 12-19.

The FTC's Final Report on the Chain-Store Investigation, S. Doc. No. 4, 74th Cong., 1st Sess. 91 (1934), rejected federal taxation of chain stores as a method of regulating distributive outlets, because "to tax out of existence the advantages of chain stores over competitors is to tax out of existence the advantages which the consuming public have found in patronizing them..." The Report feared that a graduated tax on chains "will also tend toward an arbitrary frustration of whatever saving in cost of production and distribution results from integration of the functions of producer, wholesaler, and retailer." Id. at 91-92.

64. "The citizens of the State ... may have believed that the chain store, by furthering the concentration of wealth and of power and by promoting absentee ownership, is thwarting American ideals; that it is making impossible equality of opportunity; that it is converting independent tradesmen into clerks; and that it is sapping the resources, the vigor and the hope of the smaller cities and towns."

Louis K. Liggett Co. v. Lee, 2SS U.S. 517, 568-69 (1933) (dissenting opinion). 
mately winning the competitive struggle in transportation and retail distribution, preservation of the individual businessman is socially desirable and justifies government mitigation of the rigors of the competitive process. Such a position is incomprehensible to the "performance" school of antitrust thinking. Its adherents would contend that the state should protect competition, not competitors; that such discriminatory taxation penalizes the chain stores because their performance has been too good; that the competition of a handful of chains is the optimum market structure in terms of consumer welfare. ${ }^{65}$ But to Brandeis some sacrifice of performance was apparently a cheap price to pay for industrial decentralization. ${ }^{06}$

\section{Excesses of Fair Competition}

As Brandeis pointed out in his dissent in New State Ice Co. v. Licbmann, ${ }^{\text {B7 }}$ the state might need to protect small firms from the competition of other small firms as well as from that of the large. In this case a majority of the Court held unconstitutional an Oklahoma statute which declared the manufacture and distribution of ice a public business, and which provided that no new ice plant could be constructed unless a license was first obtained from the state. The latter would be issued only if the applicant established that existing facilities were insufficient to serve the public needs. Liebmann, though unlicensed, had commenced construction of an ice plant for the purpose of competing with the New State Ice Company. When the latter sought an injunction, Liebmann asserted that the state statute violated the Fourteenth Amendment. ${ }^{08}$

A majority of the Justices refused to extend the traditional category of businesses affected with the public interest to include the ice business. The ice industry was "essentially private in its nature";" accordingly, the legislature could not constitutionally restrict the number of participants. The Court felt that the effect of the statute was to "shut out new enterprises, and thus create and foster monoply in the hands of existing establishments, against, rather than in aid of, the interest of the consuming public."70

Brandeis agreed that the purpose of the statute was to prevent competition. But he added that free competition was not necessarily beneficial to the con-

65. See Griffin, An Economic Approach to Antitrust Problens 35-36, 68-69 (1951) ; Carlston, Antitrist Policy: A Problem in Statecraft, 60 Yale L.J. 1073, 1082-83 (1.951).

Many writers have emphasized that ease of entry is an effective check against monopolization in distribution. See Galbraith, American Capitalism 148-49 (1952); Rowe, supra note 62 , at $950-51$.

66. Brandeis' endorsement of taxation as a feasible means of retarding industrial concentration is of more than mere historical interest. It has recently been suggested that federal tax policy should be influenced by the goal of promoting small business. H.R. REP. No. 2683, 83d Cong., 2d Sess. 37-46 (1954) ; H.R. Rep. No. 1610, 83d Cong., 2d Sess. 1332 (1954) ; statement by Senator Fulbright, N.Y. Times, March 16, 1956, p. 11, col. 1.

67. 285 U.S. 262 (1932).

68. Id. at $271-72,281$.

69. Id. at 277 .

70. Id. at 278 . 
sumer. In Brandeis' opinion, the Oklahoma law was not an arbitrary infringement of individual rights, but a measure justified by the economic circumstances of the industry, which he reviewed.

Because of transportation barriers the business was carried on by local plants with narrowly limited market areas. The product was undifferentiated, and a new ice plant could be constructed with relative ease. The demand of any market area for ice was inelastic. Since ice plants had a determinate productive capacity, and the costs of production were mostly fixed costs, erection of a new plant in a locality already adequately served usually resulted in cutthroat competition. These tactics eventually redounded to the disadvantage of the consumer. Both competing units might go bankrupt, in which case the community would be without any ice. If an agreement was made to share the market and each unit produced a fraction of the output, productive capacity would be idle; production costs and prices would be higher than necessary, because of the declining average cost schedule for the individual firm. The purpose of the legislation was to prevent the wastes inherent in "unnecessary duplication of facilities," which is "likely to bring high rates and poor service."71 Moreover, even though the statute fostered monopoly, the licensed ice plants did not have monopoly power over prices. For the state could terminate the license of any company that was not adequately serving the public. ${ }^{72}$

Like discriminatory taxation, government restriction of a potential competitor's freedom to enter an industry is inconsistent with the tenets of classical economic thought. But Brandeis observed that, in light of the high overhead and transportation costs which characterized the ice industry, unbridled competition among many producers would yield economically wasteful results. ${ }^{73}$ Under these circumstances, he was willing to sanction as a reasonable experiment ${ }^{74}$ the competitive restrictions which the statute imposed, despite his personal fear that "the remedy might bring evils worse than the present disease."75

71. Id. at 282; see also id. at 291-92.

72. Id. at 304.

73. "A certificate of public convenience and necessity ... was unknown to the common law. ... [Its] introduction in the United States ... marked the growing conviction that under certain circumstances free competition might be harmful to the community and that, when it was so, absolute freedom to enter the business of one's choice should be denied."

Id. at 282 .

74. For discussion by Brandeis of the state's constitutional power to experiment in the interest of solving social and economic problems, see $i d$. at 310-11.

75. Id. at 309. Brandeis doubted whether any governmental agency could successfully perform the huge task of determining when construction of another ice plant somewhere within the state would serve the public interest. See $i d$. at 309-10. The economic planning under scrutiny in the Ncw State case was for him a substitution of the inefficiencies of "big government" for the evils accompanying unrestricted entry into the industry. Thus, Brandeis would probably have voted against the law if he had been a member of the Oklahoma legislature, unless he would have felt that the alternative was state socialization of the industry. See note 76 infra and accompanying text. 
It should also be noted that one of the consequences of the policy adopted by the Oklahoma legislature was to foster small business. For even with the establishment of the series of local monopolies contemplated by the statute, the average plant in the Oklahoma ice industry would remain a small one, just large enough to serve the needs of the natural market area immediately around it. Unless the state restricted freedom of entry, a multiplicity of small firms would either destroy one another or provide inadequate service. And, if private firms could not assure a sufficient supply at reasonable prices, Brandeis warned that the state itself might decide to operate the ice business. ${ }^{76}$ Thus, to preserve a market structure predicated on small, privately run concerns, Brandeis had again sanctioned governmental interference with the competitive process.

\section{Competition and the Shernan Act}

Brandeis' economic philosophy influenced his interpretation of the broad language of the Sherman Antitrust Act. ${ }^{77}$ His opinions reflect the belief that the main purpose of the legislation was to curb the concentration of industrial power in the American economy and prevent the annihilation of small business.

\section{"Restraints" Promoting Competition}

Brandeis spoke for a unanimous Court in 1918, when he declared that the "call" rule of the Chicago Board of Trade did not violate section 1 of the Sherman Act. ${ }^{78}$ This rule prohibited members of the Board from offering to purchase, during the period between business sessions, grain "to arrive"7s at a price other than the closing bid of the preceding session. Brandeis rejected the government's contention that an agreement fixing the offering price of grain during an extended time period was per se an illegal restraint of trade..$^{0}$ He held that the Court must ascertain whether the nature and effect of the

76. Id. at 304-05. Brandeis noted that, under prior Court decisions, the due process clause would not prevent a state from engaging in the business of supplying its residents with necessary commodities if private enterprise failed to do an adequate job. Accordingly, Brandeis argued, a state could constitutionally exercise the lesser power of restricting entry into an industry in order to foster economic stability and aid private distributors. Since a state that decides to take over a business "may exert the taxing power all individual dealers may be driven from the calling by the unequal competition. If States are denied the power to prevent the harmful entry of a few individuals into a business, they may thus, in effect, close it altogether to private enterprise." $I d$. at 305.

77. 26 Stat. 209 (1890), 15 U.S.C. $\$ \S 1-7$ (1952).

78. Board of Trade of Chicago v. United States, 246 U.S. 231 (1918).

79. I.e., grain already in transit to the market or to be shipped within a specified time. Id. at 236.

80. "The case [of the government] was rested upon the bald proposition, that a rule or agreement by which men occupying positions of strength in any branch of trade, fixed prices at which they would buy or sell during an important part of the business Id. at 238 . day, is an illegal restraint of trade under the Anti-Trust Law." 
"restraint" were to suppress or to promote competition. ${ }^{81}$ Brandeis found that the "call" rule applied only during a part of each business day, applied only to a fraction of the grain shipped to Chicago, and had no appreciable effect on total volume or general prices. ${ }^{82} \mathrm{He}$ also maintained that adoption of the rule had distributed the business in grain "to arrive" among a far larger number of market participants than had been the case before. ${ }^{83}$

The Justice's reasoning in Chicago Board of Trade mirrored his conviction that, for purposes of the antitrust statutes, no business practice was legal or illegal per se. ${ }^{84} \mathrm{He}$ asserted that the Court should examine all relevant data and then determine whether the consequences of the price-fixing agreement attacked by the government were socially or economically beneficial. ${ }^{85}$ And

S1. "The legality of an agreement or regulation cannot be determined by so simple a test, as whether it restrains competition. Every agreement concerning trade, every regulation of trade, restrains. To bind, to restrain, is of their very essence. The true test of legality is whether the restraint imposed is such as merely regulates and perhaps thereby promotes competition or whether it is such as may suppress or even destroy competition."

Ibid.

82. Id. at 239.

83. Id. at 240 . Brandeis found that the promulgation of the "call" rule had shifted the bulk of the trading in grain "to arrive" from private transactions dominated by a few dealers to the Board's regular competitive sessions.

84. Cf. the method of analysis adopted by Brandeis in Standard Oil Co. v. United States, 283 U.S. 163 (1931). Several major oil companies had independently developed and patented cracking processes, a method of refining which increased the gasoline yield from given quantities of crude oil. The companies then formed a patent pool, whereby each competitor gained equal access to the patents of all and was released from liability for past infringements of others' patents. The pooling arrangement also included a formula for determination and division of royalties received under licensing agreements with independent concerns. The government claimed, inter alia, that such an agreement tended to increase the fees to be paid by licensees, and thus the manufacturing cost of "cracked" gasoline, through elimination of competition between the pool's members in the issuance of licenses under their respective patents.

In rejecting the contention that the pooling arrangement violated the Sherman Act, Brandeis, speaking for a unanimous Court, first asserted that patent interchange agreements among competitors "may promote rather than restrain competition" by eliminating the obstacle to technical progress inherent in potential infringement suits. Id. at 171. To determine whether the patent pool in question unreasonably restrained interstate commerce, Brandeis found it necessary to make a thorough investigation of "the operation and effect of the challenged contracts." Id. at 175 . In view of the fact that twenty-one independentlyowned cracking processes were beyond the control of the pool, and cracked gasoline constituted only $26 \%$ of total gasoline production, Brandeis concluded that competition within the industry was not impaired by defendants' control of royalty rates. "No monopoly of any kind, or restraint of interstate commerce, has been effected. . . To warrant an injunction which would invalidate the contracts here in question ... there must be a definite factual shozing of illegality." Id. at 179. (Emphasis added.) See also AtT'y Gen. ReP. 245 n.96.

85. "[T ] he court must ordinarily consider the facts peculiar to the business to which the restraint is applied; its condition before and after the restraint was imposed; the nature of the restraint and its effect, actual or probable. The history of the 
Brandeis tended to judge the results of alleged violations of the Sherman Act in terms of the dichotomy of small and big business, approving that conduct which maintained diffusion of economic power. ${ }^{86}$

\section{Resale Price Maintenance}

Prior to Brandeis' appointment, the Supreme Court had held an agreement by which a manufacturer bound dealers to resell his product at a fixed price an illegal restraint of trade. ${ }^{87}$ In 1918 the issue was again raised in Boston Store v. American Graphophone Co., ${ }^{88}$ which concerned the right of a manufacturer of patented articles to hold retailers to a designated resale price. Continuing the trend of prior cases, a majority of the Court reiterated that the price-fixing contract was "contrary to the general law" and "not within the monopoly conferred by the patent law." "99 Yielding to the principle of

restraint, the evil believed to exist, the reason for adopting the particular remedy, the purpose or end sought to be attained, are all relevant facts."

Board of Trade of Chicago v. United States, 246, U.S. 231, 238 (1918).

Brandeis took no part in the consideration or decision of the famous case of United States v. Trenton Potteries Co., 273 U.S. 392 (1927), which, by a 5-3 vote, established the maxim that price-fixing agreements are conclusively presumed to violate the Sherman Act. See also United States v. Socony-Vacuum Oil Co., 310 U.S. 150, 228 (1940) ("[P] ricefixing combinations ... are illegal per se; they are not evaluated in terms of their purpose, aim or effect in the elimination of so-called competitive evils."). Trenton Pottcries distinguished the Chicago Board of Trade case as referring to the temporary maintenance of a price determined by competitive forces on the floor of an exchange; see $i d$. at 401 . Nevertheless, in view of the language and focus of Brandeis' opinion in the earlier case, he would probably have disapproved the broad holding in Trenton Potteries, which compelled courts to invalidate price-fixing agreements without considering the economic circumstances of which they were a product. The opinion of Chief Justice Hughes in Appalachian Coals, Inc. v. United States, 288 U.S. 344 (1933), clearly bears the Brandeis imprint; see especially $i d$. at 360-61.

See also statement of Prof. Milton Handler, Hearings Before the Subcommittec on Antitrust and Monopoly of the Senate Committee on the Judiciary on a Study of the Antitrust Lawes, 84th Cong., 1st Sess., pt. 1, at 36-39 (1955). Prof. Handler testified that one factor which in the past had increased the difficulties of antitrust enforcement was the interpretation of the rule of reason by Justice Brandeis in the Chicago Board of Trade case. Since this construction required a factual showing of illegality in each case and deemed relevant evidence relating to trade conditions and the nature of the restraint effected, the scope of litigation was broadened to almost unmanageable proportions.

86. It is today accepted doctrine that, under the rule of reason guiding the judicial application of the Sherman Act, courts have discretion to determine only whether a restraint of trade constitutes an "undue limitation on competitive conditions," Standard Oil Co. v. United States, 221 U.S. 1, 58 (1911) ; see ATT'Y GEN. REP. 11; note 115 infra. Brandeis, however, was more concerned with the welfare of small business units than with the unfettered operation of competitive processes; this orientation influenced his own interpretation of the Sherman Act. See notes 91-99, 107-14 infra and accompanying text.

87. Dr. Miles Medical Co. v. John D. Park \& Sons Co., 220 U.S. 373 (1911); of. Bauer \& Cie v. O'Donnell, 229 U.S. 1 (1913) ; Bobbs-Merrill Co. v. Straus, 210 U.S. 339 (1908).

88. 246 U.S. 8 (1918).

89. Id. at 25 . 
stare decisis, Brandeis concurred in the Court's holding. But he clearly indicated his doubts as to the wisdom of the result. A manufacturer's right to fix resale prices was "an economic question," to be decided by reference to "relevant facts, industrial and commercial, rather than established legal principles." 00

Brandeis had long been an ardent supporter of resale price maintenance and had publicly attacked the Court's decisions in the previous price-fixing cases. ${ }^{01}$ In the absence of price standardization, the small producer and retailer were the ones who suffered injury, ${ }^{92}$ and unwittingly the community fostered concentration within the manufacturing and distribution segments of the economy. Brandeis felt that the large producer, through its dominant power, was always able to obtain conformity to a fixed price, even without entering into a contract. ${ }^{93}$ If necessary, the great corporation, with its substantial volume of sales, could establish its own retail outlets and deal directly

90. Id. at 27-28. Brandeis joined the dissenters in the later cases of FTC v. Beech-Nut Packing Co., 257 U.S. 441 (1922), and United States v. A. Schrader's Son, Inc., 252 U.S. 85 (1920), which held illegal schemes to maintain minimum resale prices.

91. Brandeis, Cutthroat Prices-The Competition That Kills, Harper's Weekly, Nov. 15, 1913, p. 10; see also A. T. Mason, Brandeis: A Free Man's Life 424-28 (1946).

92. "The public interest clearly demands that price standardization be permitted; and it demands it in the first place in the interest of the small man [-] the small manufacturer, the small producer, and the small retailer. Ultimately also of the consumer. . . ; but primarily in the competition of the small man as against the big one."

Statement of Brandeis, Hearings Beforc the Honse Committee on Interstate and Foreign Commerce on Regulation of Prices, 64th Cong., 1st Sess. 201 (1915).

93. "The denial of the right to establish standing prices results in granting a privilege to the big concerns; a discrimination in favor of the rich and powerful as against the small man; for the concern with large capital, as the powerful trusts, can secure adherence to the standard price, while the small manufacturer or producer can not. The small man needs the protection of the law; but the law becomes the instrument by which he is destroyed. The rule laid down by the Supreme Court [in the cases cited note 87 supra] is inconsistent with the business policy adopted by this country and recently confirmed by the Clayton Act and in the Federal trade act-the policy of regulating competition."

Ibid.

In other pronouncements prior to 1916, Brandeis had employed the term "regulated competition" to denote the detection and prevention by the government of unfair methods of competition. See note 34 supra and accompanying text. One of Brandeis' arguments in iavor of price standardization was the protection of the consumer from the bait of "loss leading"; see Hearings Before the Committee on Regulation of Prices, supra note 92, at 205-06. Although price-cutting branded articles to lure purchase of overpriced merchandise may be deemed an unfair competitive practice, price maintenance contracts prevent a retailer from cutting prices regardless of his economic motive. Cf. Herman, $A$ Note on Fair Trade, 65 Y ALE L.J. 23, 29 (1955); see also note 99 infra and accompanying text.

Brandeis believed that the elimination of competition at the retail level by price standardization would not impair competition at the manufacturing level. "Nearly every standard-priced article is a competitive article. Competition is the automatic price regulator." Hearings Before the Committee on Regulation of Prices, supra note 92, at 207; see also id. at 212, 219; Brandeis, Cutthroat Prices-The Competition That Kills, Harper's 
with the consumer. ${ }^{94}$ It was the small producer who needed the power to fix resale prices. $^{95}$ For competitive price-cutting at the retail level not only impaired the value of the product in the mind of the consumer but also, because of the shrinkage in profit margin, made the individual dealers less eager to handle the product. As a result, the small manufacturer might find himself driven from the market. ${ }^{96}$

Resale price maintenance, Brandeis insisted, would also preserve a multiplicity of small retail outlets. When price standardization was illegal, to avoid price cutting, the manufacturer of a trade-marked article usually sold it to only one distributor in each market area. ${ }^{97}$ The dealer who handled the product was inevitably a large unit, like the department store. As a result, the small independent retailer was gradually exterminated. With uniform resale pricing, new spheres of merchandising would be opened up:

"The whole world can be drawn into the field. Every dealer . . . can be made a purveyor of [an] article, and you have stimulated, through the fixed price, the little man as against the department store, and as against the large unit which may otherwise monopolize [retail] trade." "1s

Thus, in order to retain smallness and a healthy diffusion of economic power in both manufacturing and retailing, Brandeis again advocated a partial abandonment of competitive principles. Dealers should no longer be free to lower the designated prices of trade-marked goods, even if such price-cutting represented rational economic behavior in view of the demand and cost factors confronting the individual merchant. ${ }^{99}$ This restriction, Brandeis felt, would

Weekly, Nov. 15, 1913, p. 11. ("No man is bound to compete with himself.") ; Brandeis, On .Laintaining Maker's Prices, Harper's Weekly, June 14, 1913, p. 6, reprinted in ThE Curse of Bigness 125 (Fraenkel ed. 1934); cf. Adams, Resale Price Maintcnance: Fact and. Fancy, $64 \mathrm{Y}_{\mathrm{ALE}}$ L.J. 967,972 (1955). Such reasoning has been criticized for its failure to recognize the connection between resale price maintenance and price stabilization in oligopolistic industries. When each oligopolist fixes its own retail price, it cannot avoid responsibility, and will invite inevitable reprisals, if it seeks to undercut the prevailing market price. See Stacking \& Watkins, Monopoly and Free Enterprise 323 n.15 (1951).

94. Hearings Before the Committee on Regulation of Prices, supra note 92, at 202, 238; Brandeis, Cutthroat Prices-The Competition That Kills, Harper's Weekly, Nov. 15, 1913 , pp. 11, 12.

95. " $[T]$ he prohibition of price-maintenance imposes upon the small and independent producers a serious handicap. Some avenue of escape must be sought by them; and it may be found in combination." Id. at 12 .

96. Ibid.

97. Ibid.

98. See statement of Brandeis, Hearings Before the Subcomnittee on the Oldficld Revision of Patent Statutes of the House Committee on Patents, 62d Cong., 2d Sess., no. 18, at 3-25 (1912). The quoted passage is reprinted in The Socral and Econosic VIEws of Mr. Justice Brandeis 401 (Lief ed. 1930).

99. Cf. FTC, Report on Resale Price Maintenance lxiv (1945):

"The purpose of [the Miller-Tydings amendment to the Sherman Act] is not to legalize contracts whose object is to prevent predatory price cutting for an ulterior 
tend to put the large and small distribution units on equal terms, and preclude the control of retail trade by the giant concern.

\section{Trade Associations of Snlall Producers}

In the 1921 American Column \& Lumber case, ${ }^{100}$ the Supreme Court debated the legality of a trade association's activities under section 1 of the Sherman Act. 365 producers of hardwood lumber, who jointly controlled thirty per cent of the industry's output, had entered into an "Open Competition Plan." Under this arrangement, each competitor submitted to a central clearing house information on sales, prices, purchasers and stocks on hand, supplemented by estimates of future production and market conditions. ${ }^{101}$ The association then prepared a digest of this data, which it distributed to members of the pool. Accompanying these reports was the interpretation of a skilled market analyst, including "significant suggestions" as to both future prices and output. ${ }^{102}$ Frequent meetings were held, at which members were urged to avoid "overproduction."

The Court found that the main purpose and result of the Plan were to restrict output and thereby raise prices, "regardless of cost or merit."103 Although no specific agreement to this effect had been consummated, the Court felt that the disposition of members to cooperate in furtherance of common goals, combined with the publicity incident to detailed reports on each competitor's operations, were an effective guarantee of the Plan's success. The Court was convinced by the evidence that the Plan was designed to effectuate cooperative exploitation of the market, and not merely to facilitate an enlightened independent judgment by each producer. ${ }^{104}$ Such concerted action

purpose. The antitrust laws do not condemn such contracts. The . . amendment legalizes contracts whose object is to require all dealers to sell at not less than the resale price stipulated by contract without reference to their individual selling costs or selling policies."

Sce also Stocking \& Watrins, Monopoly and Free Enterprise 322, 330 (1951). For further discussion of the pros and cons of fair trade, see notes 121, 123 infra and accompanying text.

100. American Column \& Lumber Co. v. United States, 257 U.S. 377 (1921).

101. Id, at 394-95. Every member of the Plan was required to make a daily report of all sales made, including the names of buyers, the quality of the lumber sold, and the prices charged. In addition, members made monthly reports showing production during the previous month and stock on hand.

102. Id. at 399 .

103. Id. at 409 .

10f. "Genuine competitors do not make daily, weekly and monthly reports of the minutest details of their business to their rivals, as the defendants did. . . This is not the conduct of competitors but ... of men united in an agreement, express or implied, to act together and pursue a common purpose under a common guide. . .." Id. at 410 .

The majority opinion summarily rejected defendants' contention that the purpose of the Hlan was merely to provide widely scattered market participants with trade data, similar to that disseminated in newspaper and government publications. The Court observed that 
by naturally competing dealers was held "inconsistent with that free and unrestricted trade which the statute contemplates shall be maintained."105

The dissenting opinion of Mr. Justice Brandeis reflects his concern for the welfare of small business. Brandeis insisted that the cooperative conduct of individual enterprises which the Court had condemned was not an illegal restraint of trade but an effort to make "rational" competition possible. He considered the Open Competition Plan a feasible means of supplying competitors with relevant trade data not otherwise available. For hardwood lumber mills were widely scattered, and most of them were located away from principal markets. Unless facilities were established to disseminate information to all producers, the firms located near the large centers would gain an advantage over the isolated firms, and the large concern, which was able to establish its own bureau of statistics, would enjoy a marked superiority over the small concern. By making the facts available to every rival, the trade association created a healthy freedom of opportunity. ${ }^{106}$

So much of Brandeis' views did not necessarily differ from thase of the majority. And for Brandeis the increase in market prices which was perpetrated through the trade association, and which was stressed by the majority, was insufficient evidence of illegal collusion. The cooperating members of the association had not created a monopoly or coerced trade rivals :

"It may be that the distribution of the trade data, the editorial comment and the conferences enabled the producers to obtain, on the average, higher prices than would otherwise have been possible. But . . . the illegality of a combination under the Sherman Law lies not in its effect upon the price level, but in the coercion thereby effected."107

Brandeis warned that a refusal to permit such cooperative behavior by a multitude of small producers might eventually cause a centralization of industrial power in the hands of one giant unit. For unrestricted competition among independent concerns might lead to such a shrinkage of profit margins that competitors would be induced to consolidate in order to improve their economic position. Brandeis pointed out that, under prior Court decisions, such control of thirty per cent of an industry's output by a single corporation

published reports were available to buyer and seller alike, while the information collected by the association was distributed only to sellers. In addition the majority opinion pointed out that newspaper publication of market data was not analyzed by a specialist for the common elucidation of trade rivals. Id. at 411-12.

105. Id. at 409.

106. Id. at 415-16. But cf. note 104 supra and accompanying text.

In several pronouncements prior to his appointment to the Court, Brandeis had emphasized the importance of access of all competitors to relevant trade data. See statement before Federal Trade Commission, April 30, 1915, printed in The Soctal and Econonryc Views of Mr. Justrce Branders 411-15 (Lief ed. 1930); address, The Democracy of Business, Feb. 5, 1914, printed in THE CuRSE OF Bigness 137, 140-42 (Fraenkel ed. 1934).

107. American Column \& Lumber Co. v. United States, 257 U.S. 377, 417-18 (1921). (Emphasis added.) 
would not per se violate the antitrust laws. ${ }^{108}$ And the emergence of a single huge enterprise in the hardwood lumber business would necessarily be accompanied by those social hazards incident to bigness. ${ }^{109}$

Joint action by independent competitors to restrict their production and thereby raise prices would draw sharp condemnation from supporters of classical competitive principles. Such collusive conduct would represent an effort to maximize total profit by approximating the level of output which would be set by a single-firm monopolist. ${ }^{110}$ Similarly, a contemporary observer evaluating the economic performance of the industry would conclude that consumers were obtaining less goods at higher prices than would prevail in the absence of competitive restraints. ${ }^{111}$

For Brandeis, however, these standards were not the test by which the conduct of the industry under scrutiny should be judged. In his opinion, the main object of the Sherman Act was not to secure optimum economic results. Rather, the Act aimed at bigness; it was intended to prevent the existence of the market power incident to industrial concentration. ${ }^{112}$ And, since the

108. Brandeis referred to United States v. United States Steel Corp., 251 U.S. 417 (1920), and United States v. United Shoe Machinery Co., 247 U.S. 32 (1918).

109. "May not these hardwood lumber concerns, frustrated in their efforts to rationalize competition, be led to enter the inviting field of consolidation? And if they do, may not another huge trust with highly centralized control over vast resources, natural, manufacturing and financial, become so powerful as to dominate competitors, wholesalers, retailers, consumers, employees and, in large measure, the community?"

American Column \& Lumber Co. v. United States, 257 U.S. 377, 419 (1921). Cf. note 95 supra.

Brandeis thus pointed out a dilemma in antitrust enforcement which still exists today: that though loose-knit combinations of independent competitors are readily invalidated under the "per se" doctrines, different standards may prevail in determining the legality under the Sherman Act of a merger of competitors. Cf. United States v. Columbia Steel Co., 334 U.S. 495, 521-23 (1948) ("per se" doctrine not applied to instances of vertical and horizontal integration in the steel industry). See also the dissenting opinion of Douglas, J., in Standard Oil Co. v. United States, 337 U.S. 293, 315 (1949). Justice Douglas disapproved the Court's invalidation of Standard Oil's exclusive supply contracts with independent dealers, because he believed that "the elimination of these requirements contracts sets the stage for Standard and the other oil companies to build service-station empires of their own." Id. at 320. "The method of doing business under requirements contracts at least leeps the independents alive. They survive as small business units. . . The requirements contract which is displaced is relatively innocuous as compared with the virulent growth of monopoly power which the Court encourages." Id. at 319-21.

110. See Stocking \& Watkins, Monopoly and FreE Enterprise 234, 237, 255 (1951); cf. Bain, Price Theory 209-10 (1952).

111. Such was the conclusion of Stocking in The Rule of Reason, Workable Competition, and the Legality of Trade Association Activities, 21 U. CHI. L. REv. 527, 544-46 (1954).

112. Cf. the dissenting opinion of Douglas, J., in United States v. Columbia Steel Co., 334 U.S. 495, 535-36 (1948) :

"We have here the problem of bigness. Its lesson should by now have been burned into our memory by Brandeis. The Curse of Bigness shows how size can become 
goal of the Act was diffused economic power, those restraints of trade which section 1 condemned were coercive ones, that is, restraints intended to foster market dominance by restricting the freedom of existing competitors or preventing the entry of new ones. In terms of Brandeis' antitrust objectives, the "Open Competition Plan" served the same purpose as resale price mainteance; though restraints on competition, they both tended to preserve smallness and were therefore legal. Any price increase which accompanied their operation was the premium society paid to avoid the curse of bigness. ${ }^{113}$ A restriction of competitive conditions, though economically harmful, had again been deemed by Brandeis a political and social necessity. ${ }^{114}$

a menace-both industrial and social. . . In final analysis, size in steel is the measure of the power of a handful of men over our economy. That power can be utilized with lightning speed. It can be benign or it can be dangerous. The philosophy of the Sherman Act is that it should not exist. For all power tends to develop into a government in itself. Power that controls the economy should be in the hands of elected representatives of the people, not in the hands of an industrial oligarchy. Industrial power should be decentralized. . . . That is the philosophy and command of the Sherman Act."

See also the dissenting opinion of Douglas, J., in Standard Oil Co. v. United States, 337 U.S. 293, 318 (1949). For further discussion of Brandeis' views on the relation of the antitrust laws to bigness, see Ernst, Justice Brandeis' Frve Porwts 10 (Brandeis Lawyers' Soc'y 1947).

113. In 1911 Brandeis had indicated his belief that an agreement among a multiplicity of independent competitors regulating prices and production was less serious than the control of an industry by a single corporate unit. The association of independents "is far less objectionable than the large aggregations, because it leaves, in respect to . . management and production, absolute independence, and it is limited only in respect to selling price and market. . . [I]t particularly does not lead to those evils which are attendant upon large aggregations. ..."Interstatc Commerce Hearings 1249. Brandeis also maintained that he conceived it "perfectly possible that a state of affairs might arise under which it might be necessary, in order to preseric competition, to allow some kind of trade agreements." Id. at 1250 . (Emphasis added.) But he indicated he was not satisfied that any such condition existed at that time. Ibid. See also Brandeis, The Solution of the Trust Problem, Harper's Weekly, Nov. 8, 1913, p. 19. And cf. Brandeis' dissenting opinion in Louis K. Liggett Co. v. Lee, 288 U.S. 517, 577-79 (1933) (cooperation of independently owned retail storcs to obtain advantages of size considered preferable to chains of stores owned by single corporate unit).

Brandeis' assertion that trade agreements regulating prices and production were consistent with the preservation of competition foreshadowed his later emphasis on the protection of small competitors rather than the free play of competitive economic forces.

1.14. Brandeis agreed with the opinion of the Court in the four other cases concerning trade association activities which the Court decided while he was a member. In Maple Flooring Manufacturers Ass'n v. United States, 268 U.S. 563 (1925), the Court approved an association of twenty-two lumber producers, distinguishing American Colum on the ground that, in the instant case, the Government had not shown "any agreement or any concerted action with respect to prices or production," id. at 586. Much of Justice Stone's language in Maple Flooring endorsing the exchange of information on average production costs, sales and inventories resembles Brandeis' defense of "rational" competition in his American Column dissent. Compare American Column \& Lumber Co. v. United States, 257 U.S. 377, 415-17 (1921) (dissenting opinion), with Maple Flooring Manufacturers 


\section{ConCLUSION}

Mr. Justice Brandeis' writings and opinions indicate the conflict between competition and smallness as alternative goals of national policy. Both these standards have influenced our present public policy toward market structures. Promotion of competition has been generally accepted as the basic objective of the antitrust laws. ${ }^{115}$ But although legislation has attempted to advance competition in the industrial sector of the economy, it has simultaneously limited competition in other sectors. Present agricultural policy evinces a clear lack of satisfaction with a competitive determination of farm prices and output. ${ }^{110}$ The Miller-Tydings Act, ${ }^{117}$ the McGuire Act, ${ }^{118}$ and the state fair trade laws were designed to eliminate price competition in a large area of retail distribution. ${ }^{119}$ The Robinson-Patman Act was an effort to help the independent businessman survive the competition of the mass distributor. ${ }^{120}$

For many observers such governmental efforts to restrict the operation of competitive forces are unwarranted deviations from the principle of free competition on which the American economy is predicated. The fair trade laws have been widely attacked as inconsistent with antitrust policies, since they are considered to deprive the consumer of the benefits of price competi-

Ass'n v. United States, supra at 582-84. The Maple Flooring decision is criticized in Stocking, supra note 111, at 546-66. In Cement Manufacturers Protective Ass'n v. United States, 268 U.S. 588 (1925), an association of nineteen cement producers was held not in violation of the Sherman Act; the Court found the association was formed primarily to serve legitimate business goals and not to suppress competition among members.

Brandeis also concurred in the unanimous opinion of the Court in United States v. American Linseed Oil Co., 262 U.S. 371 (1923), invalidating an association of twelve manufacturers of linseed products that jointly controlled "a very large part" of the national industry, $i d$. at 380 . Brandeis' willingness to condemn this association, despite his approval of the two associations in the lumber industry, is explicable in terms of the large market share which the competitors in Linseed collectively enjoyed, the relatively large size of each individual competitor, $i d$. at 389, and the "coercive" system of fines imposed on nonconforming members, $i d$. at 382, 389, cf. text at note 107 supra. Brandeis was also a member of the Court when it unanimously dissolved an association of fifteen sugar refining companies in Sugar Institute, Inc. v. United States, 297 U.S. 553 (1936). Here, as in Linsecd, the members of the association were themselves relatively large business units, and together supplied 70-80\% of the national consumption of sugar. Id. at 571-72.

115. Atr'y Gen. Rep. 1; see, e.g., United States v. Socony-Vacuum Oil Co., 310 U.S. 150, 218, 221-22 (1940) ; Northern Securities Co. v. United States, 193 U.S. 197, 337-38 (1904); United States v. Joint-Traffic Ass'n, 171 U.S. 505, 569 (1898).

116. See EdWards, Maintaining Conipetition 62-66 (1949); Stocking \& Watkins, Monopoly and Free Enterprise 392-400, 537 (1951) ; Benedict, Attempts to Restrict Competition in Agriculture: The Government Programs, 44 AM. Econ. Rev. 93 (Supp. 1954).

117. 50 Star. 693 (1937), 15 U.S.C. \$ 1 (1952), amending 26 Stat. 209 (1890).

118. 66 Stat. 631, 15 U.S.C. $\$ 45$ (1952), amending 38 Stat. 719 (1914).

119. FTC, Report on Resale Price Maintenance passim (1945).

120. H.R. REP. No. 2287, 74th Cong., 2d Sess. (1936); S. REP. No. 1502, 74th Cong., 2d Sess. (1936) ; cf. FTC, Final Report on the Chain-Store Investigation, S. Doc. No. 4, 74th Cong., 1st Sess. (1934). 
tion in retailing. ${ }^{121}$ Similarly, commentators have objected to the anti-competitive focus of the Robinson-Patman Act; they contend that enforcement of this statute has denied the public price advantages flowing from the free operation of competitive forces in distribution. ${ }^{122}$

Such criticism of competitive restrictions may be sound from the point of view of consumer welfare. But the fact is that the legislation under attack is a boon to small business. ${ }^{123}$ And the message of Mr. Justice Brandeis is that economic performance standing alone provides an inadequate standard for judging the effects of such competitive restraints. Not to be overlooked are the social and political advantages which may accompany the preservation of the small businessman and the diffusion of concentrated economic power. There are strong arguments that freedom of opportunity vanishes and individual initiative deteriorates "when a nation of shopkeepers is transformed

121. ATT'Y GEN. REP. 149-54 (Fair trade "is at odds with the most elementary principles of a dynamic free enterprise system.") ; Enwards, Maintaining Competimion 6673 (1949) ("There is no more reason to protect distributors from price competition than to protect manufacturers."); FTC, Report on Resale Price Matntenance lix-lxiv (1945) ("[T] he consumer is . . entitled . . . to competition between dealers handling the same branded product.") ; STocking \& WATKINs, MoNopoly aNd FREE ENTERPRISE 32130, 561 (1951) ("From the standpoint of the public interest in revitalizing competitive forces, resale price maintenance is objectionable whatever group sponsors it.") ; Hcarings Before the Subcommittee on Antitrust and Monopoly of the Senate Committce on the Iudiciary on a Study of the Antitrust Lawes, 84th Cong., 1st Sess., pt. 1, at 15-20, 67-69, 255, 273 ; pt. 2 , at $578,616,624$ (1955).

122. AtT'y Gen. Rep. 164-65, 171-72, 177, 190, 207-08; Edwards, Mianntaining Conipetition 166-69 (1949) ; United States Dep't of Comrarce, Effective Conpetition $1,5,7$ (1952) (Robinson-Patman "is a legal barbed wire entanglement that discourages competition in favor of protecting competitors.") ; STockIng \& WatkIns, Monopoly aND Free ENTERPRISE 538-39, 561 (1951); Hearings Before the Subcommittee on Antitrust and Monopoly, supra note 121, pt. 1, at 81-82, 201, 256, 272-73, 397-98; pt. 2, at 616-18, 624; Rowe, supra note 62, at 972-75; Learned \& Isaacs, The Robinson-Patman Law: Some Assumptions and Expectations, 15 HARv. Bus. Rev. 137, 139 (1937) ("an anti-competition statute slipped into the anti-trust laws") ; Burns, The Anti-trist Laws and the Regulation of Price Competition, 4 Law \& Contemp. Prob. 301, 308-09 (1937) ; cf. Standard Oil Co. v. FTC, 340 U.S. 231, $249 \&$ n.15 (1951).

123. "Robinson-Patman helps keep small businessmen in business by relieving them of some of the worst risks of competition, and this may be bad economics but it is arguably good policy." Rahl, Antitrust Policy in Distribution, 104 U. PA. L. REv. 185, 192 (1955). See also statement of President Truman when signing the McGuire Act, $1 \mathrm{CCH}$ TrADE REG. REP. (10th ed.) II 3040.10 (July 14, 1952); dissenting views in ATT'Y GEN. REP. 154-55, 220; Mermey, Fair Trade: The Fundamental Issues, 1 ANtitrust Bull. 125, 14345. (1955); Schwartz, The Schwartz Dissent, 1 id. at 37, 59; Galbraith, Connterzailing Power, 44 Am. Econ. Rev. 1, 3 (Supp. 1954) ; H.R. Rep. No. 1610, 83d Cong., 2d Sess. 84 (1954) ; remarks of representatives of small business in Hearings Before the Senate Sclect Committee on Small Business to Consider the Report of the Attorney Goneral's National Committee to Study the Antitrust Lazs, 84th Cong., 1st Sess. 101, 105, 111, 180, 182, 325 (1955) (The Robinson-Patman Act and federal fair trade laws "are the only two statutes in the federal laws today that give some semblance of protection to small business." Id. at 180.). 
into a nation of clerks," 124 that control of distribution by a handful of large companies is less desirable in a democracy than a multiplicity of independents. ${ }^{125}$ Although these noneconomic contentions have escaped the attention of many commentators, they may justify the paradoxes of present public policy.

Moreover, the social and political objections to the giant corporate unit which Brandeis stressed are likely to become of increasing importance in the adjudication of future antitrust prosecutions. For example, a representative of the Justice Department has recently suggested that the growing dominance of the nation's automotive industry by General Motors might make it a proper target for an antitrust suit. ${ }^{126}$ If the government does seek divestiture of parts of General Motors, ${ }^{127}$ such action would not seem motivated by dissatisfaction with G.M.'s present economic performance. ${ }^{128}$

However, though the concentration of force in the auto industry may lead to efficiency and progress, it also shatters the effectiveness of traditional economic restraints on market power. ${ }^{129}$ As a result, the consumer who enjoys

124. Douglas, Democracy and Finance 15 (1940); see also Fromm, Escape from Freedom 123-28 (1941); Kaplan, Satall Business: Its Place and Problens 1, 3-4 (19.4); note 64 supra.

125. See Quinn, Giant Business: Threat to Denrocracy (1953); Schwartz, supra note 123, at 38-40; E. S. Mason, The New Competition, 43 YALE REv. 37, 42, 48 (1953); notes 11,112 supra.

126. Remarks of Stanley N. Barnes, Assistant Attorney General of the United States in charge of the Antitrust Division, reported in Time, Mar. 19, 1956, p. 105; see also address by Barnes, How Business Mergers Affect the Economic Outlook of the United States, Feb. 8, 1956, pp. 10-11, 14, N.Y. Times, Feb. 9, 1956, p. 1, col. 8; statement by Barnes, Hearings Before the Subcommittee on Antitrust and Monopoly, supra note 121, pt. 1, at 295-98.

127. The government has recently filed a civil antitrust complaint charging General Motors with monopolizing the manufacture and sale of transit and intercity buses, and with conspiring with four bus operating companies to monopolize the manufacture and sale of buses. The complaint alleges that General Motors manufactured $85 \%$ of the new buses sold in the United States in 1955. The government asks, inter alia, that General Motors be enjoined from selling more than $50 \%$ of the annual bus requirements of the four operating companies named as co-conspirators. United States v. General Motors Corp., Civil No. 15816, E.D. Mich., complaint filed, 1 CCH TrADE REG. Rep. đ 66248 (July 6, 1956).

128. General Motors is generally reputed to be a well-managed and efficiently run corporation. For a picture of the company's internal workings, see DRUCKER, THE CoNCEFT OF THE CORPORATION (1946); Hearings Before the Subcommittee on Antitrust and Ifonopoly, stipra note 121, pt. 7, at 3492-844; pt. 8. Although the Staff Report of the Subcommittee on Antitrust and Monopoly, Bigness and Concentration of Economic Power -A Case Study of General Motors Corp., S. REP. No. -, S4th Cong., 2d Sess. 1-5, 12-13, 24-25, 59 (1956), suggests that checking the expansion, and divesting parts, of G.M.'s diversified organization would foster the social values of a free enterprise system, the Keport does not challenge the economic efficiency of the company in the conduct of prior business operations.

129. "I should not rely upon the goodness of heart of anybody. Neither our character nor our intelligence can long bear the strain of unrestricted power." Remark of Brandeis, May, 1905, quoted in A. T. Mason, The Brandeis Way 71 (1938). 
reasonable prices and maximum production today is denied guarantees such performance will continue. Moreover, such industrial concentration means that a few business leaders are permitted and required to make decisions which affect a considerable segment of our society. ${ }^{130}$ The exercise of such farreaching powers by a politically nonresponsible group would, to Louis Brandeis, be incompatible with the democratic tenet that governing power should be entrusted to elected representatives of the governed.

130. "There is probably no company in the United States that affects the lives of the citizens of the country as much as General Motors." Staff Report of Subcommittee on Antitrust and Monopoly, supra note 128 , at 25. General Motors, the largest manufacturing company in the world, $i d$. at 2 , employs over half a million persons, ibid., and enjoyed gross sales of $\$ 12.4$ billion in $1955, i d$. at 25 .

See also Berle, The 20th Century Capitalist Revolution c. II (1954). 